\title{
Influence of risk perception, preventive behavior, movement and environment on malaria infection in Lundu district, Sarawak, Malaysia
}

\author{
Norliza Jusoh, Shamsul Azhar Shah
}

\begin{abstract}
Abtrak
Insidensi malaria di Sarawak tertinggi di Malaysia walaupun terdapat tren penurunan sejak 2002. Tujuan kajian ini untuk mengidentifikasi faktor risiko yang berhubungan dengan infeksi malaria. Studi kasus-kontrol ini dilakukan di distrik Lundu, Sarawak. Kasus terdiri atas 96 penderita malaria yang tercatat di Dinas Kesehatan Lundu dari Januari sampai September 2005. Kontrol dipilih dari subjek yang belum pernah mengalami malaria dan berasal dari kampung yang sama dengan kasus. Distribusi kasus dan kontrol kurang lebih sama menurut umur, jumlah keluarga dan pendapatan keluarga per bulan. Dalam hal pekerjaan resiko tinggi, tepi atap, perpindahan tempat tinggal bagi yang berumur 50 tahun atau lebih, dan kepemilikan mobil lebih banyak dilaporkan oleh kasus ketimbang kontrol. Usia tua, lelaki, taraf sosioekononi rendah dan persepsi fatalitas malaria mempertinggi risiko terjangkit malaria. Dibandingkan perempuan, lelaki berisiko tujuh kali lipat terjangkit malaria [odds rasio suaian $\left(O R_{a}\right)=7,09 ; 95 \%$ interval kepercayaan $(I K)=3,21$ 15,65]. Subjek dengan persepsi fatalitas malaria berisiko lebih dari enam kali lipat terjangkit malaria $\left(O R_{a}=6,38 ; 95 \%\right.$ CI $=1,32-$ 30,87) dibanding dengan yang tanpa persepsi tersebut. Sebaliknya, subjek dengan pendapatan per kapita per bulan rendah dibandingkan dengan yang tinggi berisiko 85\% lebih rendah untuk menderita malaria $\left(O R_{a}=0,15 ; 95 \%\right.$ CI =0,03-0,72). Usia tua, lelaki, pendidikan dan taraf sosioekonomi rendah, dan persepsi fatalitas malaria yang rendah atau sanitasi lingkungan yang rendah mempertinggi risiko terjangkit malaria. (Med J Indones 2007; 16:267-71)
\end{abstract}

\begin{abstract}
The incidence of malaria in Sarawak is among the highest in Malaysia despite its downward trend since 2002. This study was conducted to identify the dominant risk factors related to malaria infection. A case-control study was conducted in Lundu District, Sarawak. Cases were 96 indigenous malaria cases registered from January to September 2005 at Lundu District Health Office. Controls were selected among those who never contracted malaria originating from the same villages as cases. Cases and control were similarly distributed with respect to age, number of household and total household income per month. Cases were more likely than controls to report high risk occupation, opened eaves, ever had movement for those aged 50 years or over and car ownership. Older age, male, lower socioeconomic level and perception of fatality toward malaria increased risk to malaria infection. Male than female had seven-fold risk to be malaria infected [adjusted odds ratio $\left(O R_{a}\right)=7.09 ; 95 \%$ confidence interval $(C I)=3.21-15.65$ ]. In term of perception of fatality toward malaria, those who did not have than did have perception of fatality toward malaria had six-fold risk to be malaria infected $\left(O R_{a}=6.38 ; 95 \% C I=1.32-30.87\right)$. On contrary, those who had lower than middle and high per capita income per month had $85 \%$ lowered risk to be malaria infected $\left(O R_{a}=0.15 ; 95 \% C I=0.03-0.72\right)$. Male, older age, lower education and socioeconomy level, lower perception towards malaria, or lower environment sanitation had increased risk to be malaria infected. (Med J Indones 2007; 16:267-71)
\end{abstract}

Keywords: malaria, gender, sosioeconomics, perception, protective personal measure, environmental

It is estimated that 300 million people were infected by malaria with more than a million deaths throughout the world. ${ }^{1}$ In Malaysia, malaria incidence had decreased from 23.4 cases per 10,000 population in 1991 to 2.8 cases per 10000 population in 2003 . $^{2}$ The

Department of Community Health, Faculty of Medicine, Universiti Kebangsaan Malaysia, Kuala Lumpur, Malaysia incidence of malaria in the state of Sarawak is among the highest in Malaysia despite its downward trend since 2002. In 2003, the incidence was 11.8 cases per 10,000 population which was the highest among the state. $^{2}$ Kuching Division was among the divisions that recorded incidence of more than 10 cases per 10,000 population in the same year of which Lundu District contributed more than $50 \%$ of all malaria cases for the division. ${ }^{3,4}$ In view of this, the study was carried out 
to identify the factors influencing malaria infection among the people of Lundu District, Sarawak with the emphasis on knowledge, risk perception, preventive behaviour, movement, and environment.

\section{METHODS}

Lundu District is the part of Kuching Division that is bordered by West Kalimantan, Indonesia and located $96 \mathrm{~km}$ southwest of Kuching City. Geographically, it comprises of forests and hilly landforms that are divided by valleys and deep ravines while the coastal area is filled with secondary forests, farmlands and oil palm plantations. There are 33.909 populations in Lundu with the main ethnic groups are Bidayuh (Land Dayak), Iban (Sea Dayak), Malay and Chinese. Most of them are farmers of which pepper, rubber and paddy are the main crops. Others work as labourers in the land development scheme for oil palm or working in the government and private sectors.

The design of the study was an unmatched case-control study of which Lundu population became the target study population. A total of 96 symptomatic and asymptomatic indigenous malaria cases confirmed by blood film malaria parasite (BFMP) that were registered from January to September 2005 at Lundu District Health Office were selected as cases. Controls were selected through simple random sampling among those who never contracted malaria originating from the same villages as cases and confirmed by negative BFMP. The case to control ratio was one control to one case. Only those aged 17 years and above were included in the study because they were expected to answer questions related to perception and knowledge.

Face-to-face interviews were conducted by trained health personnel using questionnaire consisted of sections on sociodemographic data, knowledge, perception, preventive behaviour and movement. Knowledge and perception towards malaria were assessed through related questions and each correct answer was given a score of one. The total scores were then categorised into good or low knowledge and risk perception (cut off point 13 and 4 respectively). Behavioural risk factors considered in this study were the use of treated bed nets, acceptance of indoor regular spraying, the use of protective personal measures and movement. The definition of movement in this study was movement from one place (usually place of residence) to another and eventually returns back for economic or social purposes and not taking into account the distance from the residence. Besides that, observation of the respondents' environment was also done including the house structure, house design and potential mosquito breeding sites. Blood were taken for BFMP through finger prick to confirm malaria status of controls on the day of the interview.

Data collected from the field were coded and analysed with SPSS software version 12.0. Logistic regression was performed to calculate relative risk and to identify dominant risk factors related to malaria infection as well as to control for potential confounder.

\section{RESULTS}

There were 131 indigenous malaria cases registered at Lundu District Health Office throughout the study period. Adults aged between 20 to 60 years were $74.8 \%$ while $20.6 \%$ were children and adolescent.

Cases and control were similarly distributed with respect to age, number of household and total household income per month. Cases were more likely than controls to report high risk occupation, opened eaves, ever had movement for those aged 50 years or over, asset ownership car (Table 1). Meanwhile, no significant association was found for knowledge and preventive behaviour such as the usage of bednets, house spraying and the usage of preventive protective measures

Table 2 shows that older age, male, lower socioeconomics level and perception of fatality toward malaria were increased to be malaria. The most prominent factors were gender and perception of fatality toward malaria. Male than female had seven-fold risk to be malaria infection. In term of perception of fatality toward malaria, those who did not have than did have perception of fatality toward malaria had six-fold risk to be malaria. On contrary, those who had lower than middle and high per capita income per month had $85 \%$ lowered risk to be malaria infection. 
Table 1. Some demographic, socioeconomic characteristics of subject and risk of malaria

\begin{tabular}{|c|c|c|c|c|c|}
\hline & $\begin{array}{c}\text { Control }(\mathrm{N}=96) \\
\mathrm{n}(\%)\end{array}$ & $\begin{array}{c}\text { Case }(\mathrm{N}=96) \\
\mathrm{n}(\%)\end{array}$ & $\begin{array}{l}\text { Crude } \\
\text { odd ratio }\end{array}$ & $\begin{array}{c}95 \% \\
\text { Confidence interval }\end{array}$ & $\mathrm{P}$ \\
\hline \multicolumn{6}{|l|}{ Occupation } \\
\hline Low risk & $55(57.3)$ & $36(37.5)$ & 1.00 & Reference & \\
\hline High risk & $41(42.7)$ & $60(62.5)$ & 2.24 & $1.25-3.99$ & 0.006 \\
\hline \multicolumn{6}{|c|}{ Total household income/month } \\
\hline Middle and high & $12(12.5)$ & $10(10.4)$ & 1.00 & Reference & \\
\hline Low & $84(87.5)$ & $86(89.6)$ & 1.23 & $0.50-2.99$ & 0.719 \\
\hline \multicolumn{6}{|l|}{ Opened eaves } \\
\hline No & $64(66.7)$ & $16(16.7)$ & 1.00 & Reference & \\
\hline Yes & $32(33.3)$ & $80(83.3)$ & 2.50 & $1.26-4.96$ & 0.008 \\
\hline \multicolumn{6}{|l|}{ Potential breeding site } \\
\hline \multicolumn{6}{|l|}{100 m from house to: } \\
\hline \multicolumn{6}{|l|}{ Forest } \\
\hline No & $29(30.2)$ & $34(35.4)$ & 1.00 & Reference & \\
\hline Yes & $67(69.8)$ & $62(64.6)$ & 0.79 & $0.43-1.44$ & 0.442 \\
\hline \multicolumn{6}{|l|}{ River/stream } \\
\hline No & $67(69.8)$ & $63(65.6)$ & 1.00 & Reference & \\
\hline Yes & $29(30.2)$ & $33(34.4)$ & 1.21 & $0.66-2.22$ & 0.537 \\
\hline \multicolumn{6}{|l|}{ Movement } \\
\hline None & $19(19.8)$ & $11(11.5)$ & & Reference & \\
\hline Less than 50 years & $57(59.4)$ & $69(71.9)$ & 3.11 & $1.21-7.98$ & 0.014 \\
\hline 50 years or more & $20(20.8)$ & $16(16.7)$ & 0.20 & $0.02-1.97$ & 0.184 \\
\hline \multicolumn{6}{|c|}{ Asset ownership (Does not own)* } \\
\hline Television & $8(8.3)$ & $14(14.6)$ & 1.88 & $0.75-4.710 .72-2.70$ & 0.174 \\
\hline Radio & $21(21.9)$ & $27(28.1)$ & 1.40 & $1.22-4.940 .86-3.25$ & 0.317 \\
\hline Car & $66(68.8)$ & $81(84.4)$ & 2.45 & & 0.011 \\
\hline Refrigerator & $19(19.8)$ & $28(29.2)$ & 1.67 & & 0.131 \\
\hline
\end{tabular}

Table 2. Relationship between several demographic, socio-economic, knowledge and risk of malaria infection

\begin{tabular}{|c|c|c|c|c|c|}
\hline & $\begin{array}{c}\text { Control }(\mathrm{N}=96) \\
\mathrm{n}(\%)\end{array}$ & $\begin{array}{c}\text { Case }(\mathrm{N}=96) \\
\mathrm{n}(\%)\end{array}$ & $\begin{array}{c}\text { Adjusted } \\
\text { odds ratio* }\end{array}$ & $\begin{array}{c}95 \% \\
\text { Confidence interval }\end{array}$ & $\mathrm{P}$ \\
\hline \multicolumn{6}{|c|}{ 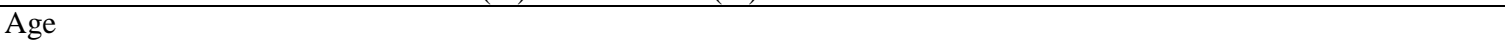 } \\
\hline 50-78 years & $21(21.9)$ & $20(20.8)$ & 1.00 & Reference & \\
\hline 17-49 years & $75(78.1)$ & $76(79.2)$ & 2.76 & $1.04-7.34$ & 0.041 \\
\hline \multicolumn{6}{|l|}{ Gender } \\
\hline Female & $63(65.6)$ & $29(30.2)$ & 1.00 & Reference & \\
\hline Male & $33(34.4)$ & $67(69.8)$ & 7.09 & $3.21-15.65$ & 0.000 \\
\hline \multicolumn{6}{|l|}{ Education level } \\
\hline Secondary school & $44(45.8)$ & $31(32.2)$ & 1.00 & Reference & \\
\hline Primary school & $30(31.3)$ & $42(43.8)$ & 2.79 & $1.16-6.70$ & 0.022 \\
\hline No & $22(22.9)$ & $23(24.0)$ & 3.29 & $1.06-10.22$ & 0.039 \\
\hline \multicolumn{6}{|l|}{ Total household income } \\
\hline Middle and high & $12(12.5)$ & $10(10.4)$ & 1.00 & Reference & \\
\hline Low & $84(87.5)$ & $86(89.6)$ & 3.55 & $0.82-15.34$ & 0.089 \\
\hline \multicolumn{6}{|l|}{ Per capita income } \\
\hline Middle and high & $6(6.3)$ & $16(16.7)$ & 1.00 & Reference & \\
\hline Low & $90(93.8)$ & $80(83.3)$ & 0.15 & $0.03-0.72$ & 0.017 \\
\hline \multicolumn{6}{|l|}{ Owned motorcycle } \\
\hline Yes & $75(78.1)$ & $56(58.3)$ & 1.00 & Reference & \\
\hline No & $21(21.9)$ & $40(41.7)$ & 2.64 & $1.20-5.82$ & 0.016 \\
\hline \multicolumn{6}{|l|}{ Perception of malaria } \\
\hline Fatal disease & $93(96.9)$ & $86(89.6)$ & 1.00 & Reference & \\
\hline Not fatal disease & $3(3.1)$ & $10(10.4)$ & 6.38 & $1.32-30.87$ & 0.021 \\
\hline \multicolumn{6}{|l|}{$\begin{array}{l}\text { Ceiling } \\
\text { Fully }\end{array}$} \\
\hline $\begin{array}{l}\text { Fully } \\
\text { Partly }\end{array}$ & $18(18.8)$ & $34(35.4)$ & 2.19 & $1.01-4.77$ & 0.048 \\
\hline \multicolumn{6}{|l|}{ Water-filled material } \\
\hline No & $66(68.8)$ & $49(51.0)$ & 1.00 & Reference & \\
\hline Yes & $30(31.3)$ & $47(49.0)$ & 2.41 & $1.17-4.92$ & 0.016 \\
\hline \multicolumn{6}{|c|}{ * Adjusted each others for risk factors listed on this Tabel } \\
\hline
\end{tabular}




\section{DISCUSSION}

From the study, $74.8 \%$ of the overall indigenous malaria cases in Lundu District during the study period were adults as opposed to the indigenous group of Sungkai, Perak and in South Africa which were mainly among children. ${ }^{5,6}$ This shows that malaria infection in Lundu could be influenced by adults' behaviour; movement in particular, for economic or social reasons.

Based on this case-control study, being in the younger age group (less than 50 years) and male gender were the risk factors for malaria infection. This is because they are the more mobile group and most of the time they involve in high risk activities such as hunting, fishing and work as loggers. These findings are supported by Lansang et al. who used 30 years as the cut off point for age. ${ }^{7}$ Do not attain high education level was also identified as the risk factor in this study. Those with higher education level might have better understanding on malaria and this could have influenced the behaviour towards preventive measures and in seeking treatment. Similar findings obtained by Guthmann et al. in their case-control study done in Peru. $^{8}$

On contrary, the finding for per capita income per month (OR 0.15) was the opposite from what we had expected earlier. A study done in Nigeria showed that those with higher income were protected against malaria. ${ }^{9}$ This could be explained by the number of household used to calculate per capita income was different than that of the national poverty line resulting in the possibility of misclassification of income category. The Ministry of Finance use 4.8 as the household number in calculation of the national poverty line but in this study income per capita was calculated by dividing total income with number of household that ranged from 1 to 16 . Bear in mind that estimation of income per month obtained from respondents by itself might not be accurate due to unwillingness to disclose their financial status, difficulty of valuing their own crops either due to inconsistent market price or for their own consumption. Assets ownership analysed by individual asset in this study is not a good proxy for socioeconomic status as well because most respondents owned more than one asset being studied. We might consider the use of asset indices for future study.

No significant association was found for knowledge except for the source of malaria information, knowledge on agent and vector for malaria but only at univariate level. Cases might have the same or even better knowledge than controls because they had experienced the disease and been informed about malaria when they were treated by the health personnel. In addition, risk perception could be influenced by knowledge gained through various source of information and experience as reported in The World Health Report. ${ }^{10}$ This could be the reason why there was no difference in the risk perception score between the two groups. However, knowledge score only contributed $17 \%$ in the determination of perception score as shown by correlation analysis. It means that there are other risk factors which influence risk perception not analysed in this study.

Bed net usage, house spraying and use of personal preventive measures did not show any significant findings in both univariate and multivariate analysis. Only small proportion (40.6\%) of the total respondents were actually used treated bed nets in this study which could have influenced the findings. Small sample size among those not using personal preventive measures could also explain the insignificant results. As for house spraying, only regular indoor residual spraying done every six months was taken into account during the data collection. Focal spraying which occasionally applied in certain situation was not considered even though this control measure also confers the same protection against malaria. Therefore, respondents could have misclassified under the category of house not sprayed. Meanwhile, preventive measures especially mosquito coil is usually used at home but some of the respondents were still outdoor until late night which means that they were still exposed to mosquito bite.

Movement has been identified as a risk factor after it was stratified by age which acts as the third variable in this study. The small samples among females could have contributed to the negative results when movement was stratified by gender.

Poor house design related to ceiling construction and presence of potential breeding places were the environmental factors found to have association with malaria in the study. These findings were the same as reported by Snow et al. in Peru and Staedke et al. in Uganda. ${ }^{11,12}$ Poor ceiling design actually provides access for mosquitoes to enter respondent's house and bite the occupants. Small sample size among those live in palm thatched house could have resulted in insignificant findings for house structure. Furthermore, cases and controls tend to have same type of house due to similar sociocultural background. At the same time, presence of forest and stream close to respondent's 
house were not significant risk factors. This could be due to the influence of good house design even if the house is less than $100 \mathrm{~m}$ from the forest or stream. In addition to this, controls were selected from the same village as cases; therefore, we would expect both groups live in the same environment.

As like other study, there were weaknesses and limitations in the study. Selection of controls from the same village as cases would have masked the influence of variables related to culture and environment; thus, we could not see the significant effects as expected earlier in the study. Information bias is common in casecontrol study as respondents might not be able to recall whether they were exposed to any risk factors previously. There might be situations whereby cases could recall better than controls with regards to exposure to risk factors. Besides that, misclassification might have cause insignificant or opposite findings such as per capita income category and distance estimation from house to forest or river. Finally, confounding bias could have an effect to the results in this study but this was controlled through multivariate analysis.

In conclusion, male, older age, lower education and socioeconomy level, lower perception towards malaria, or lower environment saniatation had increased risk to be malaria infection.

Behaviour modification and awareness towards malaria among the community should be enhanced through effective health education and health promotion especially with regards to improve community perception towards malaria, precautions need to be taken when people move to high risk areas and destroying potential mosquito breeding sites.

\section{Acknowledgement}

The authors would like to thank the Department of Health, Sarawak and Lundu District Health Office staffs for their assistance in data collection in the field.

\section{REFERENCES}

1. Hay SI, Guerra CA, Tatem AJ, Noor AM, Snow RW. The global distribution and population at risk of malaria: past, present and future. Lancet Inf Diseases. 2004;4:327-36.

2. Status of malaria control in Malaysia [homepage on the internet]. Disease Control Division, Ministry of Health Malaysia; 2004. Available from www.actmalaria.org/ download/pdf/info/2004. (14 Januari 2005)

3. Vector Borne Disease Control Unit, Public Health Division, Sarawak Health Department, Malaysia; 2005.

4. Vector Borne Disease Control Unit, Kuching Divisional Health Office, Sarawak, Malaysia; 2005.

5. Azmi A R. Influence of behaviour and environment on malaria infection among indigenous group of Sungkai, Perak Darul Ridwan [dissertation]. Cheras: National University of Malaysia; 1998

6. Kleinschmidt I, Sharp B. Patterns in age-specific malaria incidence in a population exposed to low levels of malaria transmission intensity. Trop Med Intrl Hlth. 2001;6(12): 986-91.

7. Lansang MAD, Belizario VY, Bustos MDG, Saul A, Aguirre A. Risk factors for infection with malaria in a low endemic community in Bataan, the Philippines. Acta Trop. 1997;63:257-65.

8. Guthmann JP, Hall AJ, Jaffar S, Palacios A, Lines J, Llanos-Cuentas A. Environmental risk factors for clinical malaria: a case-control study in the Grau region of Peru. Transactions of The Royal Soc Trop Med Hyg. 2001; 95:577-83.

9. Malaria, poverty and health: ITN-Oriade Initiative. Center for Health Sciences Training, Research and Development International; 2000.

10. Chapter 3: Perceiving risk [homepage on the internet] The World Health Report; 2002. Available from: http:// ww.who.int/whr/2002/en/chapter3.pdf. (19 April 2003)

11. Snow RW, Peshu N, Forster D. Environmental and entomological risk factors for the development of clinical malaria among children on the Kenyan coast. Transactions of The Royal Soc Trop Med Hyg. 1998;92:381-85.

12. Staedke SG, Nottingham EW, Cox J, Kamya MR, Rosenthal PJ, Dorsey G. Short report: Proximity to mosquito breeding sites as a risk factor for clinical malaria episodes in an urban cohort of Ugandan children. J Trop Med Hyg. 2003;69:244-46. 